\title{
PROPERTIES OF SELF COMPACTING CONCRETE WITH METAKAOLIN REPLACING SAND WITH GBFS
}

\author{
S. Shrihari ${ }^{1}$, Seshagiri Rao M.V ${ }^{2}$ \\ ${ }^{1}$ Associate Professor and HOD department of Civil Engineering J.B Institute of Engineering \& Technology \\ Hyderabad (Research Scholar JNTUH) \\ ${ }^{2}$ Professor, Department of Civil Engineering, JNTUH College of Engineering, Hyderabad
}

\begin{abstract}
After Agriculture Industry in India. Construction sector contribute 11\% to the GDP. Hence construction Industry plays a crucial role in economic development for any construction. Sand is the major material for preparation of mortar and self compacting concrete. But the problem here is sand is largest basic consumer non-renewable resource. Hence it is our responsibility to safeguard the sand for future generation. Today this is an almost scarcity of national sand and due to continuous excavation of river beds there is some serious effect on ecology ever. It's the time to think for alternate material to replace the river sand and for any mix design of self compacting concrete higher \%age of powder content \& sand is required. In the present paper we have put an effort to replace the sand with GBFS by-product of steel and iron manufacturing plant. Test result of GBFS meets the national standard of fine aggregates (IS 383 -1970) GBFS does not contain material that may affect the strength and durability of concrete such as chlorides, organics impurities. It is free from emission of Co2. In the present paper M40 grade of SCC was considered with different replacement of sand with G.B.F.S. Further it is studied that the effect of MetaKaolin on the properties of GBFS self compacting concrete, the studies include the effect of GBFS and MetaKaolin on the fresh and hardened mechanical properties of SCC made with GBFS and MetaKaolin. The observation made that river sand can be replaced up to $60 \%$ with constant W/C ratio $0.38 \%$ the only problem with GBFS, it takes long time to gain strength. If we add the admixtures METAKAOLIN by $10 \%$, then quick setting \& early strength is possible.
\end{abstract}

The GBFS is free from Co2, Alkalis and silt, Co2.The fresh properties \& compressive strength of SCC increases with the increase in the percentage of GBFS. But limited to $60 \%$ replacement provided by adding $10 \%$ MetaKaolin. It is found that $70 \%$ replacement not reached satisfactory results. It is economical when compared with natural sand and also reliable alternative material in terms of workability, strength and durability. As there is broader slope for advancement in construction Industry. Therefore there is an immense necessity to know for alternative to natural river sand, this paper further detail about the fresh and hardened properties chemical properties briefly in full length submission.

The fresh properties and compressive strength of self compacting concrete is improved as percentage of GBFS increases with constant MetaKaolin (\%). The study has revealed that using MetaKaolin in the replacement $f$ river sand with GBFS gives better flow properties and compressive strength in comparison to only GBFS

Keywords:, Super Plasticizer, Viscosity Modify agent, MetaKaolin, Fine aggregate replacement, Granulated Blast Furnace Slag.

\section{INTRODUCTION}

The sand is the most reliable natural material used for concreting, plastering and masonry work. The main problem is due to acute shortage, high price and enormous usage of river sand in the construction [1,2] Day by day it's getting depleted therefore sufficient amount of river sand is not available, meanwhile over use of river sand leads to damage of natural environment [3]. Hence it is desirable that a substitute which is economical is to be considered as an alternative material like GBFS [4].

GBFS is a waste industrial by-product of iron and steel production, when 1000 tons of steel is produced, nearly 400 tons of slag is obtained as a residue, the properties of this slag are similar to river sand [5], and the cost is Rs 120/ton at site, therefore it is economical compared to natural sand. Tests conducted on it are as per IS383-1970, slag sand was of zone $1[5,6]$ GBFS is non metallic granulate which possesses silicates and aluminous silicate of calcium, this helps to enhance long term strength, durability and reduction in the emission of carbon dioxide. Marine products, oversized materials, clay and silt in slag sand are nil, low pozzolanic by-product fly-ash is also used in the present work. [7, 8] It decreases early strength but improves the workability [9].

MetaKaolin is obtained from natural Kaolin clay, by heating this clay at a temperature of 650 -900 degree centigrade MetaKaolin is obtained [10, 11]. The specific surface area, silica \& alumina content of MetaKaolin is higher than O.P.C[12].During the hydration of Portland cement $\mathrm{ca}(\mathrm{OH}) 2$ 
is produced which has no contribution towards the strength development of concrete but when MetaKaolin combines with $\mathrm{ca}(\mathrm{OH}) 2$ produces additional cementation compounds and makes concrete strengthen[13,14].

In the present experimental work focused on properties of SCC using MetaKaolin with different replacement of sand by GBFS.

\section{MATERIALS USED AND ITS}

\section{PROPERTIES}

Table 1: Physical properties of MetaKaolin

\begin{tabular}{|c|c|c|c|}
\hline S.no & $\begin{array}{l}\text { Description } \\
\text { of physical } \\
\text { properties }\end{array}$ & Units & Results \\
\hline 1 & Color & & $\begin{array}{l}\text { 1Close To } \\
\text { Std }\end{array}$ \\
\hline 2 & Appearance & & $\begin{array}{l}1 \text { OFF } \\
\text { white } \\
\text { Powder }\end{array}$ \\
\hline 3 & Bulk Density & Gm/liter & 356 \\
\hline 4 & $\begin{array}{l}\text { Oil } \\
\text { Absorption }\end{array}$ & $\mathrm{Gm} / 100 \mathrm{gm}$ & \\
\hline 5 & $\begin{array}{l}\text { Moisture (EX- } \\
\text { Work) }\end{array}$ & $\%$ & 0.22 \\
\hline 6 & $\begin{array}{l}\mathrm{PH}(10 \% \text { A2 } \\
\text { Slurry) }\end{array}$ & & 6.22 \\
\hline 7 & $\begin{array}{l}\text { RESIDUE on } \\
325 \text { Mesh }\end{array}$ & $\%$ & 0.13 \\
\hline 8 & $\begin{array}{l}\text { PSD -D(50)- } \\
50 \% \text { particles }\end{array}$ & $\mu$ & 1.68 \\
\hline 9 & $\begin{array}{l}\text { Specific } \\
\text { gravity }\end{array}$ & & 2.63 \\
\hline
\end{tabular}

Table 2: Chemical Properties of MetaKaolin

\begin{tabular}{|l|l|l|l|l|l|l|}
\hline $\mathrm{SiO}_{2}$ & $\begin{array}{l}\mathrm{Fe}_{2} \mathrm{O} \\
3\end{array}$ & $\mathrm{Al}_{2} \mathrm{O}_{3}$ & $\mathrm{CaO}$ & $\mathrm{Mgo}$ & $\mathrm{k}_{2} \mathrm{O}$ & Loi \\
\hline 52. & $4.3 \%$ & 36.1 & 0.1 & 0.84 & 1.38 & 3.37 \\
$\%$ & $\%$ & $\%$ & $\%$ \\
\hline
\end{tabular}

Table 3: Physical Properties of fine aggregate GBFS (Granulated Blast furnace clay sand)

\begin{tabular}{|l|l|}
\hline S.No & Source : JSW slag, Bellary \\
\hline 1 & $\begin{array}{l}\text { a)Dry Rotted bulk density } \\
1531 \mathrm{~kg} / \mathrm{m}^{3} \\
\text { b) Loose bulk density } \\
1337 \mathrm{~kg} / \mathrm{m}^{3}\end{array}$ \\
\hline 2 & Specific gravity \\
& 2.67 \\
\hline 3 & Water absorption \\
& $6.5 \%$ \\
\hline 4 & Sieve Analysis \\
\hline
\end{tabular}

Table 4: Chemical properties of GBFS

\begin{tabular}{|c|c|c|c|}
\hline S.No & Characteristics & $\begin{array}{l}\text { Requirement as } \\
\text { per IS- } 12089\end{array}$ & $\begin{array}{l}\text { Test } \\
\text { Results }\end{array}$ \\
\hline 1 & $\mathrm{SIO}_{2}(\%)$ & - & 32.51 \\
\hline 2 & $\mathrm{AL}_{2} \mathrm{O}_{3}(\%)$ & - & 21.76 \\
\hline 3 & $\mathrm{Fe}_{2} \mathrm{O}_{3}$ & - & 1.1 \\
\hline 4 & Cao (\%) & - & 35.68 \\
\hline 5 & Mgo (\%) & 17 (Max) & 7.6 \\
\hline 6 & $\begin{array}{l}\text { Loss on Ignition } \\
\text { (\%) }\end{array}$ & & 0.35 \\
\hline 7 & IK (\%) & 5.0 (Max) & 0.45 \\
\hline 8 & $\begin{array}{l}\text { Manganese } \\
\text { Content }\end{array}$ & 5.5 (Max) & 0.15 \\
\hline 9 & Sulphide sulphur & 2.0 (Max) & 0.47 \\
\hline 10 & Glass Content & 85 (min) & 92 \\
\hline 11 & $\begin{array}{l}\text { Moisture } \\
\text { Content }\end{array}$ & - & 5.2 \\
\hline 12 & $\begin{array}{l}\text { Particle size } \\
\text { passing } 50 \mathrm{~mm}\end{array}$ & $95 \%$ & $100 \%$ \\
\hline 13 & $\begin{array}{l}\text { Chemical moduli } \\
(\mathrm{CaO}+\mathrm{Mgo}+ \\
\left.\mathrm{Al}_{2} \mathrm{O}_{3}\right) / \mathrm{siO}_{2}\end{array}$ & $\begin{array}{l}\text { Greater than or } \\
\text { equal to } 1.0\end{array}$ & 2 \\
\hline
\end{tabular}

\section{Mix Proportions of $0 \%$ MK}

Table 5: Quantities of materials for $1 \mathrm{~m} 3$ of SCC mix with $0 \%$ MetaKaolin

\begin{tabular}{|l|l|l|l|l|l|l|}
\hline $\begin{array}{l}\text { \% of } \\
\text { replaceme } \\
\text { nt of river } \\
\text { sand with } \\
\text { GBFS }\end{array}$ & $\begin{array}{l}\text { Cem } \\
\text { ent }\end{array}$ & $\begin{array}{l}\text { Fly } \\
\text { ash }\end{array}$ & $\begin{array}{l}\text { Riv } \\
\text { er } \\
\text { san } \\
\text { d }\end{array}$ & $\begin{array}{l}\text { GBF } \\
\text { S C.A }\end{array}$ & $\begin{array}{l}\text { Wat } \\
\text { er }\end{array}$ \\
\hline 0 & 351 & 207 & 876 & & 726 & 195 \\
\hline 30 & 351 & 207 & 614 & 262 & 726 & 195 \\
\hline 40 & 351 & 207 & 526 & 350 & 726 & 195 \\
\hline 50 & 351 & 207 & 428 & 438 & 726 & 195 \\
\hline 60 & 351 & 207 & 351 & 525 & 726 & 195 \\
\hline 70 & 351 & 207 & 263 & 613 & 726 & 195 \\
\hline
\end{tabular}




\section{Mix Proportions of $10 \%$ MK}

Table 6 Quantities of materials for $1 \mathrm{~m} 3$ of SCC mix with $10 \%$ MetaKaolin

\begin{tabular}{|c|c|c|c|c|c|c|c|}
\hline $\begin{array}{l}\% \text { of } \\
\text { replace } \\
\text { ment of } \\
\text { river } \\
\text { sand } \\
\text { with } \\
\text { GBFS }\end{array}$ & $\begin{array}{l}\text { Cem } \\
\text { ent }\end{array}$ & $\begin{array}{l}\text { Met } \\
\text { a } \\
\text { Kao } \\
\text { lin }\end{array}$ & $\begin{array}{l}\mathrm{Fl} \\
\mathrm{y} \\
\text { as } \\
\mathrm{h}\end{array}$ & $\begin{array}{l}\text { Riv } \\
\text { er } \\
\text { san } \\
\text { d }\end{array}$ & $\begin{array}{l}\text { GB } \\
\text { FS }\end{array}$ & $\begin{array}{l}\text { C. } \\
\text { A }\end{array}$ & $\begin{array}{l}\text { Wat } \\
\text { er }\end{array}$ \\
\hline 30 & 315 & 36 & $\begin{array}{l}20 \\
7\end{array}$ & $\begin{array}{l}61 \\
4\end{array}$ & $\begin{array}{l}26 \\
2 \\
\end{array}$ & $\begin{array}{l}72 \\
6\end{array}$ & 195 \\
\hline 40 & 315 & 36 & $\begin{array}{l}20 \\
7 \\
\end{array}$ & $\begin{array}{l}52 \\
6\end{array}$ & $\begin{array}{l}35 \\
0 \\
\end{array}$ & $\begin{array}{l}72 \\
6 \\
\end{array}$ & 195 \\
\hline 50 & 315 & 36 & $\begin{array}{l}20 \\
7 \\
\end{array}$ & $\begin{array}{l}43 \\
8 \\
\end{array}$ & $\begin{array}{l}43 \\
8 \\
\end{array}$ & $\begin{array}{l}72 \\
6 \\
\end{array}$ & 195 \\
\hline 60 & 315 & 36 & $\begin{array}{l}20 \\
7\end{array}$ & $\begin{array}{l}35 \\
1\end{array}$ & $\begin{array}{l}52 \\
5\end{array}$ & $\begin{array}{l}72 \\
6\end{array}$ & 195 \\
\hline 70 & 315 & 36 & $\begin{array}{l}20 \\
7\end{array}$ & $\begin{array}{l}26 \\
3\end{array}$ & $\begin{array}{l}61 \\
3\end{array}$ & $\begin{array}{l}72 \\
6\end{array}$ & 195 \\
\hline
\end{tabular}

Table 7: property of SCC with 0\% MetaKaolin.

\begin{tabular}{|l|l|l|l|l|l|l|}
\hline $\begin{array}{l}\text { \% of } \\
\text { replace } \\
\text { ment } \\
\text { of river } \\
\text { sand } \\
\text { with } \\
\text { GBFS }\end{array}$ & $0 \%$ & $30 \%$ & $40 \%$ & $50 \%$ & $60 \%$ & $\begin{array}{l}70 \\
\%\end{array}$ \\
\hline $\begin{array}{l}\text { Slump } \\
\text { flow }\end{array}$ & $700 \mathrm{x}$ & $\begin{array}{l}630 \mathrm{x} \\
630\end{array}$ & $\begin{array}{l}600 \mathrm{x} \\
600\end{array}$ & $\begin{array}{l}560 \mathrm{x} \\
560\end{array}$ & $\begin{array}{l}500 \mathrm{x} \\
500\end{array}$ & $\begin{array}{l}28 \\
0\end{array}$ \\
\hline $\begin{array}{l}\text { V- } \\
\text { Funnel }\end{array}$ & $5 \mathrm{sec}$ & $6 \mathrm{sec}$ & $8 \mathrm{sec}$ & $\begin{array}{l}13 \\
\mathrm{sec}\end{array}$ & $\begin{array}{l}16 \\
\mathrm{sec}\end{array}$ & $\begin{array}{l}18 \\
\mathrm{se} \\
\mathrm{c}\end{array}$ \\
\hline L-box & 0.86 & 0.72 & 0.7 & 0.64 & 0.62 & $\begin{array}{l}0 . \\
6\end{array}$ \\
\hline
\end{tabular}

Table 8: Fresh properties of SCC With 10\% MetaKaolin.

\begin{tabular}{|c|c|c|c|c|c|c|}
\hline $\begin{array}{l}\% \text { of } \\
\text { replac } \\
\text { ement } \\
\text { of river } \\
\text { sand } \\
\text { with } \\
\text { GBFS }\end{array}$ & $0 \%$ & $30 \%$ & $40 \%$ & $50 \%$ & $60 \%$ & $70 \%$ \\
\hline $\begin{array}{l}\text { Slump } \\
\text { flow }\end{array}$ & $\begin{array}{l}720 x \\
720 \\
\end{array}$ & $\begin{array}{l}680 x \\
680 \\
\end{array}$ & $\begin{array}{l}630 x \\
630 \\
\end{array}$ & $\begin{array}{l}600 x \\
600\end{array}$ & $\begin{array}{l}550 x \\
550\end{array}$ & $\begin{array}{l}350 x \\
350 \\
\end{array}$ \\
\hline $\begin{array}{l}\text { V- } \\
\text { Funnel }\end{array}$ & $\begin{array}{l}4 \\
\text { sec }\end{array}$ & $\begin{array}{l}4.5 \\
\text { sec }\end{array}$ & $\begin{array}{l}1 \\
\text { sec }\end{array}$ & $\begin{array}{l}11 \\
\text { sec }\end{array}$ & $\begin{array}{l}15 \\
\text { sec }\end{array}$ & $\begin{array}{l}16 \\
\text { sec }\end{array}$ \\
\hline L-Box & 0.91 & 0.84 & 0.8 & 0.75 & 0.72 & 0.68 \\
\hline
\end{tabular}

Table 9: Compressive strength values for SCC (in Mpa)

\begin{tabular}{|c|c|c|c|c|}
\hline \multirow{2}{*}{$\begin{array}{l}\% \text { of } \\
\text { replacement of } \\
\text { river sand with } \\
\text { GBFS }\end{array}$} & \multicolumn{2}{|c|}{$\begin{array}{l}\text { Compressive } \\
\text { strength } 7 \text { days }\end{array}$} & \multicolumn{2}{|c|}{$\begin{array}{l}\text { Compressive } \\
\text { strength } 28 \\
\text { days }\end{array}$} \\
\hline & $\begin{array}{l}0 \% \\
\text { M.K }\end{array}$ & $\begin{array}{l}10 \% \\
\text { M.K }\end{array}$ & $\begin{array}{l}0 \% \\
\text { M.K }\end{array}$ & $\begin{array}{l}10 \% \\
\text { M.K }\end{array}$ \\
\hline $0 \%$ & 30 & & 43 & \\
\hline $30 \%$ & 30 & 35 & 45 & 51 \\
\hline $40 \%$ & 30.8 & 36.2 & 46.1 & 53 \\
\hline $50 \%$ & 32.1 & 37.1 & 47 & 55 \\
\hline $60 \%$ & 33 & 38 & 48.6 & 55.8 \\
\hline $70 \%$ & 34.2 & 39 & 47.5 & 51 \\
\hline
\end{tabular}

\section{MIX PROPORTIONS}

The experimental study was done for concrete grade m40 to evaluate the result after replacing river sand by GBFS using MetaKaolin five trial mixes were done and best mix were adopted. The present work was carried out with different replacement of sand by GBFS and cement with $36 \%$ of flyash, same result of work compared with replacing cement by using $10 \%$ MetaKaolin. In both the cases (w/c) ratio is 0.37 and replacement of sand with GBFS $0 \%, 30 \%, 40 \%$, $50 \%, 60 \%, 70 \%$, totally six mixes were preferred without and with replacement of cement by MetaKaolin.

\section{RESULTS AND DISCUSSION}

River sand contains high percentage of silt, clay, and other impurities. It reduces the strength of concrete; hence it makes useless concrete for construction. GBFS is free from all above characteristics. Hence replacement of sand with GBFS gives the satisfactory results.

To improve the fresh properties and compressive strength cement is replaced with $10 \%$ of MetaKaolin The specific surface area of MetaKaolin is higher than OPC .It helps to improve the strength and other properties. During the hydration of Portland cement ca $(\mathrm{OH}) 2$ is produced when MetaKaolin combines with $\mathrm{ca}(\mathrm{OH}) 2$. It develops additional cementing compounds and it makes concrete stronger.

\section{Test on Fresh Properties of SCC}

\subsection{Fresh Properties of SCC}

1. The diameters of slump flow for different concrete mixes were measured in the range of $700 \mathrm{~mm}$ to $500 \mathrm{~mm}$ up to $60 \%$ replacement and it is reduced to $280 \mathrm{~mm}$ for $70 \%$ replacement. Same mix by replacing cement with $10 \%$ MetaKaolin $720 \mathrm{~mm}$ to $550 \mathrm{~mm}$ up to $60 \%$ replacement and it reduces to $350 \mathrm{~mm}$ for $70 \%$ replacement.

2. V- funnel flow time increase from 5 s to 16 s up to $60 \%$ of replacement and $18 \mathrm{~s}$ for $70 \%$ of replacement, Same result of work with $10 \%$ MetaKaolin flow time from $4 \mathrm{~s}$ to $15 \mathrm{~s}$ and 16 s for $70 \%$. 
3. The blocking ratio $(\mathrm{H} 2 / \mathrm{H} 1)$ for $\mathrm{L}-$ box is from 0.86 to 0.6 up to $70 \%$ replacement but same result of work with $10 \%$ MetaKaolin is from 0.91 to 0.68 . The concrete mix flow increases by using MetaKaolin.

\subsection{Compressive Strength}

The results showed that there was an enhancement in the compressive strength up to $60 \%$, replacement by $9 \%$ for 7 days and $13 \%$ for 28 days without the use of MetaKaolin By using MetaKaolin for replacement of $60 \%$ sand with GBFS, compressive strength of 7 days increased by $27 \%$ and 28 days by $31 \%$

\section{Graphs}

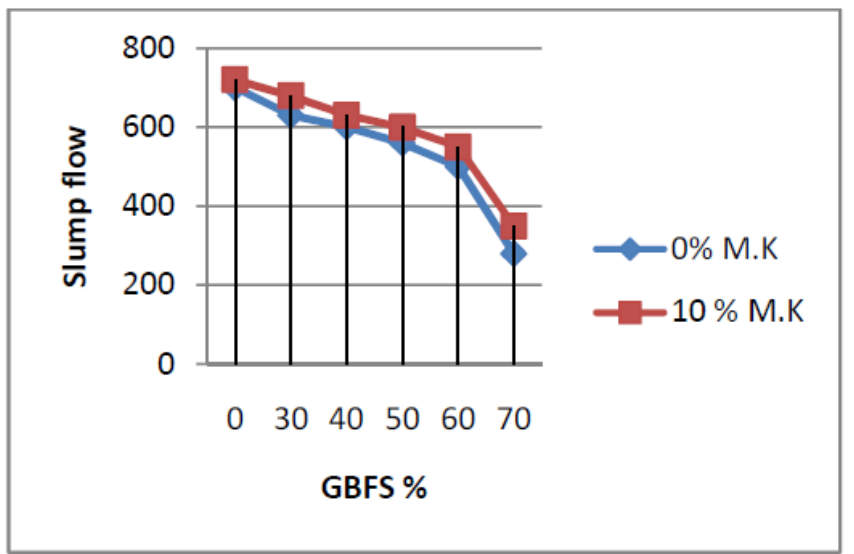

Graph1

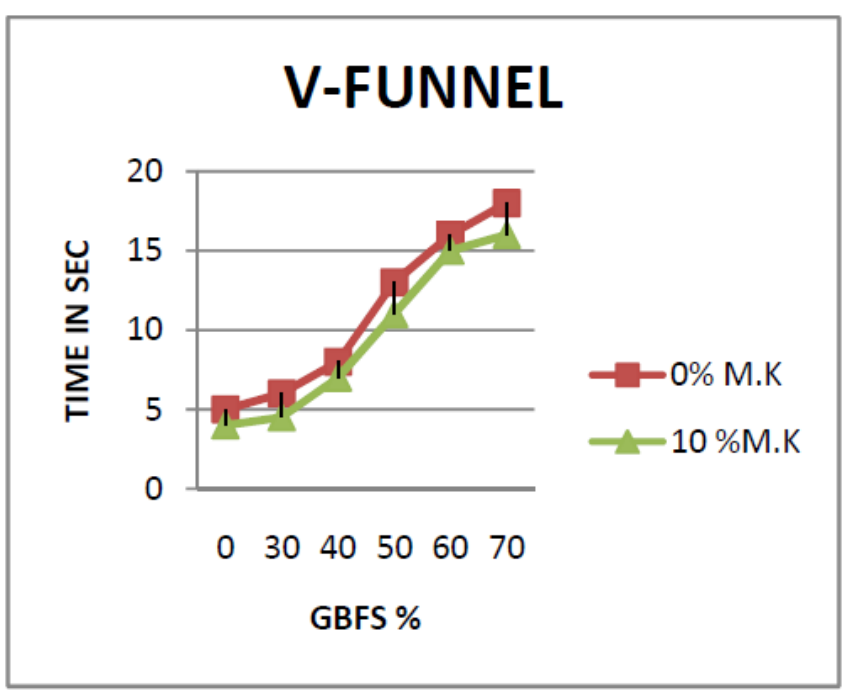

Graph2

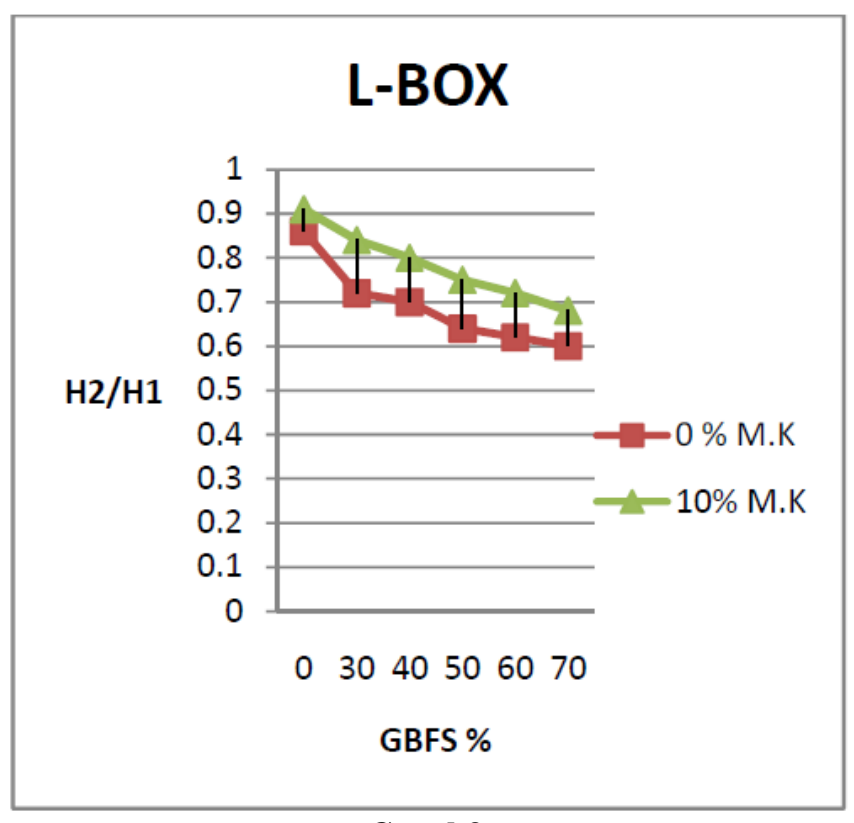

Graph3

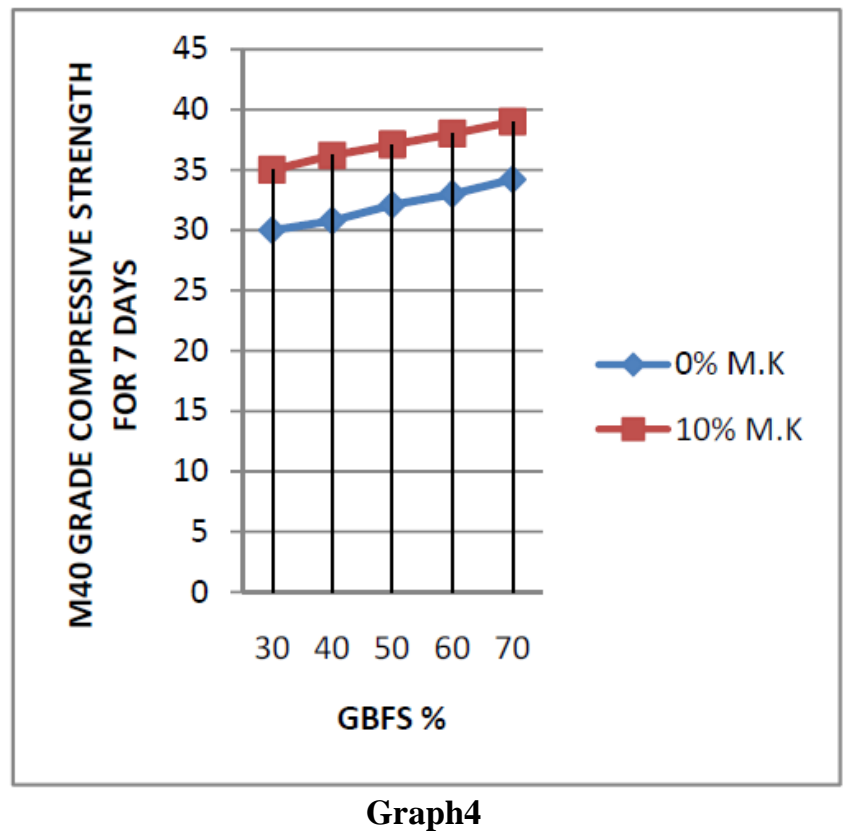

Graph4 


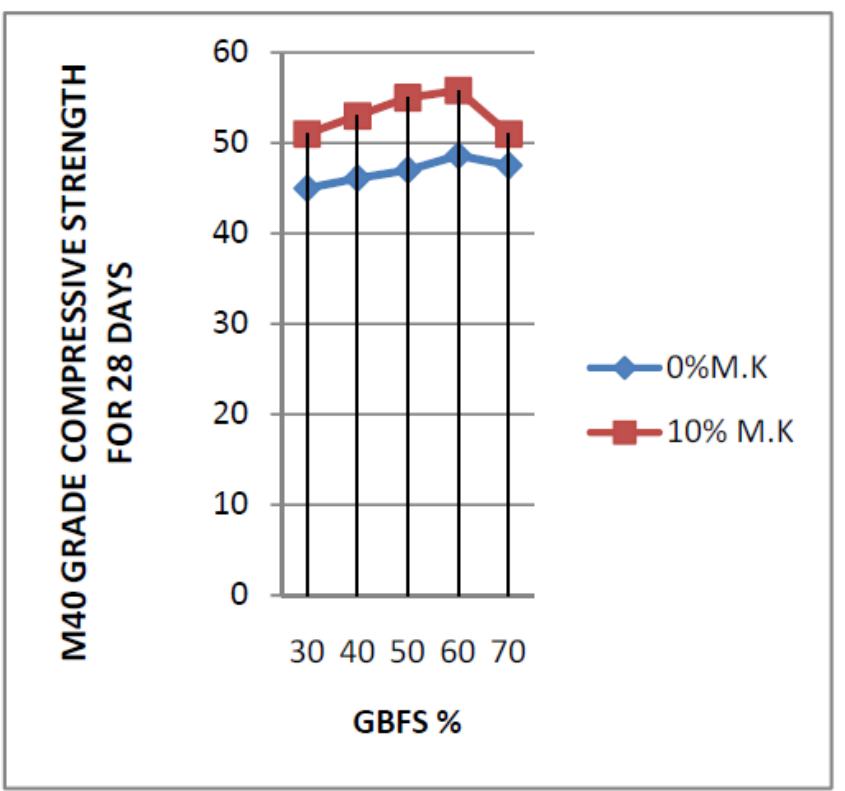

Graph5

\section{CONCLUSION}

1. Fresh properties of SCC replacing up to $60 \%$ of sand with GBFS were found to be good.

2. Fresh properties of concrete mix decreases above $60 \%$ replacement of sand with GBFS.

3. Fine particles of GBFS of $150 \mu$ and $75 \mu$ are very less hence $100 \%$ replacement of GBFS is not possible.

4. It is advisable to mix at least $30-40 \%$ of river sand with GBFS.

5. In the trial mixing, it was found that use of MetaKaolin decreases workability of SCC, but this can be improved by using super

plasticizer and change in w/b ratio 6. During the hydration of cement $\mathrm{Ca}\left(\mathrm{OH}_{2}\right)$ will be produced, it

7. By replacing cement with MetaKaolin, $\mathrm{Ca}\left(\mathrm{OH}_{2}\right)$ will be converted into (C-S-H) gel, this will help to develop to additional compressive strength and makes the concrete stronger by blocking existing pores

\section{REFERENCES}

[1]. Ramadevi K Sindubala, johnpaul. V, Kumaragaru college of technology coimbotore "Determination of optimum percentage replacement of fine aggregate in concrete using GBFS".

[2]. M.C Nataraj, P G Dileep kumar,A S Manu and M C Sanjay, use of granulated blast furnace slag as fine aggregate in cement motar, Int. J. structure \& civil Engineering and Ubanism,2013,Vol3.176-182.

[3]. Ambroise J. Maximillen S. Pera J (1994). Properties of metakaolin blended cements. Adv Cem Mater 1(4):161-168 [4]. Aziz MAE, Aleem SAE, Heikal M, Didamony HE (2005). Hydration and durability of sulphate-resisting and slag cement blends in caron's Lake water. Cem. Concr. Res. 35(8): 1592-1600

[5]. EFNARC (2002) specification and guidelines for self compacting concrete. Association House. UK.
[6]. Chen S.D, Granulated Blast Furnace Slag Used to Reduce Grounding Resistance, IEE Proc-Gener. Vol151, No3.

[7]. A.K Mullick (2007) "Performance of concrete with binary and ternary cement blends" The Indian Concrete Journal, January 2007, 15-22.

[8]. S. Venkateshwara Rao M.V. Seshagiri Rao and P.Ratihish kumar "Effect of size of aggregate and fines on standard and high strength self-compacting concrete Applied Science research, 6(5): 433-442, 2010.

[9]. Sabir BB, Wild S, Khatib. On the Workability and strength development of MetaKaolin concrete.

[10]. D.K, singha Roy, performance of Blast Furnace Slag concrete with partial Replacement of sand by Fly Ash, International journal of Earth Science and Engineering. Volume 4,October 2011.

[11]. B.B.Sabir, S.Wild, J.Bhai.. Metakoil., MetaKaolin and calcined clays as apozzolans for concrete: a review cement and concrete composites 23 .

[12]. Chan Li, Henghu Sun, Longtu Li, A review : The comparison between alkali-activated slag ( $\mathrm{Si}+\mathrm{Ca})$ and metakaolin $(\mathrm{Si}+\mathrm{Al})$ cements. Cement and Concrete Research 40 (2010) 1341-1349.

[13]. N.Krishna Murty, N.Aruna, A.V.Narasimha Rao, I.V.Ramana Reddy, B.Madhusudana Reddy and M.vijaya Sekhar Reddy, Influence of MetaKaolin and Fly ash on Fresh and Hardened properties of Self Compacting concrete, International Journal of Advanced Research in Engineering \& Technology (IJARET),Volume 4, Issue 2, 2013, pp. 223239.

[14]. Vilas V. Karjini, Shrishail B. Anadinni, Mixture Proportion procedure for SCC Indian concrete journal June 2009 pp 35-41. 